Dept. of Food Hygiene,

Fac. Vet. Med., Assiut Univ.

\title{
ASSESSMENT OF HEAVY METAL IN LOCAL AND IMPORTED FILLETED FISH IN ASSIUT CITY, EGYPT
}

(With 3 Tables)

\author{
By \\ DOAA M. ABD EL-AZIZ and Z.M. ZAKY*
}

* Dept. of Forensic Med. and Toxicology, Fac. of Vet. Med., Assiut Univ.

(Received at 5/6/2010)

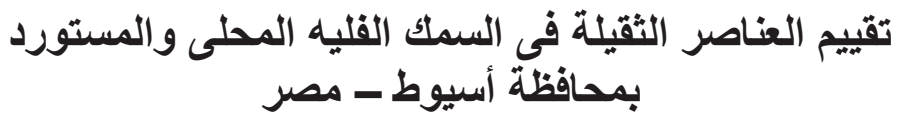

\section{دعاء محمد عبل العزيز ، زكريا مختار زكى}

هذه الدراسة أجريت لتحديد تركيزات بعض العناصر الثقبلة (الرصاص، الكادميوم، المنجنيز،

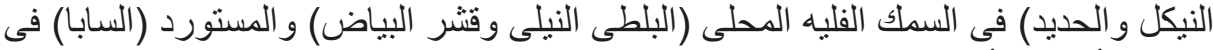

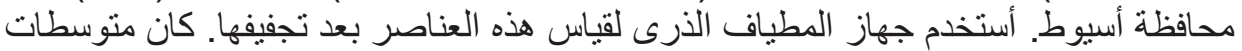
التركيز ات لعناصر الرصاص، الكادميوم، المنجنيز، ، النيكل و الحديد كالأنى:

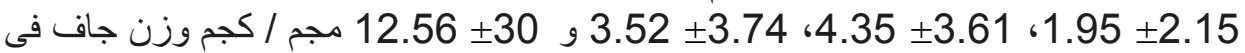
السمك الفليه المحلى، بينما كان في السمك الفليه المستورد كالأتى:

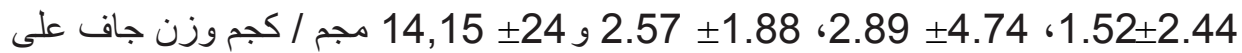

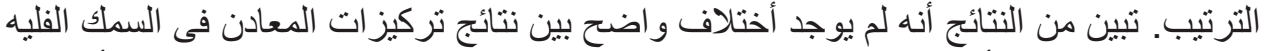

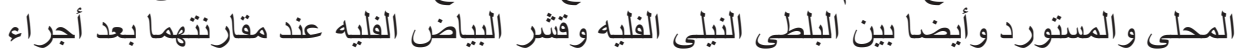

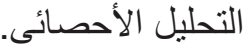

\section{SUMMARY}

Heavy metal $(\mathrm{Pb}, \mathrm{Cd}, \mathrm{Mn}, \mathrm{Ni}$, and $\mathrm{Fe}$ ) concentrations in the local (Tilapia nilotica and Nile perch) and imported (Saba) filleted fish were investigated in Assiut city using Atomic Absorption Spectrophotometer (AAS). The mean values of $\mathrm{Pb}, \mathrm{Cd}, \mathrm{Mn}, \mathrm{Ni}$ and $\mathrm{Fe}$ were 5.17 \pm 4.91 , $2.15 \pm 1.95,3.61 \pm 4.35,3.74 \pm 3.52$ and $30 \pm 12.56 \mathrm{mg} / \mathrm{kg}$ dry weight in local filleted fish, while in imported fish they were $6.90 \pm 4.035,2.44 \pm 1.52$, $4.74 \pm 2.89,1.88 \pm 2.57$ and $24 \pm 14.15 \mathrm{mg} / \mathrm{kg}$ dry weight, respectively. There was no significant difference in heavy metals concentrations between local filleted and imported filleted fish and also between filleted Tilapia nilotica 
and Nile perch in case of $\mathrm{Ni}$ and $\mathrm{Fe}$, but Tilapia nilotica higher than Nile perch in case of $\mathrm{Pb}, \mathrm{Cd}$ and $\mathrm{Mn}$ after statistical analysis.

Key words: Heavy metal, filleted fish.

\section{INTRODUCTION}

Fish is a valuable source of high quality protein, polyunsaturated fatty acids, minerals and vitamins, the health benefits of which are widely recognized. Recently, public confidence has been shaken by reports that highlighted the risks associated with dietary exposure to environmental contaminants, such as trace elements which are known to accumulate in fish. Heavy metal residues in fish flesh and its hazard effects on the health of people are a matter of great concern to food hygienists. There was a seasonal variation in heavy metals concentration and also heavy metals accumulate differentially in fish organs (Mansour and Sidky, 2002).

The pollution of water with heavy metals has become a worldwide problem during the last decade, because most of pollutants have toxic effects on organisms (MacFarlane and Burchett, 2000). Studies from the field and laboratory experiments showed that accumulation of heavy metals in a tissue is mainly dependent upon water concentrations of metals and exposure period; although some other environmental factors such as salinity, $\mathrm{pH}$, hardness and temperature play significant roles in metal accumulation. Ecological needs, sex, size and molt of marine animals were also found to affect metal accumulation in their tissues (Kalay et al., 1999).

Metals are considered as major environmental pollutants causing cytotoxic, mutagenic and carcinogenic effects in animals (More et al., 2003). The essential metals can also be toxic when the metal intake is more than needed (Tüzen, 2003). Heavy metals including both essential and nonessential elements have a particular significance in ecotoxicology (Storelli et al., 2005). Metal ions can be incorporated into food chains and concentrated in aquatic organisms to a level that affects their physiological state. Metals are of particular concern, due to their potential toxic effect and ability to bioaccumulate in tissues (Censi et al., 2006). Heavy metals such as copper, iron, chromium and nickel are essential metals, but cadmium and lead are non-essential metals, as they are toxic, even in trace amounts (Fernandes et al., 2008).

Cadmium toxicity resulted in osteomalacia (Friberg, 1984). Lead toxicity resulted in anemia, disorders of C.N.S. including hyper-activity and in severe cases headache, muscular tremors and loss of memory, kidney failure, convulsion, coma and death (Shibamoto and Bjeldanes, 
1993). High doses of copper may lead to Wilson's disease characterized by destruction of nerve cells, liver cirrhosis, ascites, edema and hepatic failure (Guven et al., 1999).

Khaled (2004a) investigated heavy metal $(\mathrm{Cd}, \mathrm{Cr}, \mathrm{Cu}, \mathrm{Fe}, \mathrm{Mn}, \mathrm{Ni}$, $\mathrm{Pb}$ nd $\mathrm{Zn}$ ) concentration in five fish species collected from El-Mex Bay, Alexandria. The author reported that metal concentrations were lowest in muscle and highest in gill and liver tissues due to their physiological roles in fish metabolism where the metabolic activity is higher. So there is no risk yet for human consumption of flesh of these fishes.

The objective of this study was to determine the heavy metals concentrations $(\mathrm{Pb}, \mathrm{Cd}, \mathrm{Mn}, \mathrm{Ni}$, and $\mathrm{Fe})$ in filleted fish using Atomic Absorption spectrophotometer (AAS) technique and compare between local and imported fish fillet, also to compare between Tilapia nilotica and Nile perch.

\section{MATERIALS and METHOD}

\section{Samples collection:}

Fifty samples of local (Tilapia nilotica (13) and Nile perch (12)) and imported (Saba) (25) filleted fish were collected from Assiut city retail markets during first half of year 2010 and analyzed for determine the concentration of several types of metals $(\mathrm{Pb}, \mathrm{Cd}, \mathrm{Mn}, \mathrm{Ni}$ and $\mathrm{Fe})$. The collected samples were transferred to the laboratory were kept under freezer at $-18^{\circ} \mathrm{C}$ until analyzed.

\section{Preparation of samples for analysis:}

Fifty gm of fish fillet were weighted from each dried in a hot air oven $\left(100-105^{\circ} \mathrm{C}\right)$ till the wet tissues reached to a constant weight According to (AOAC, 2006). Moisture content of each sample was calculated, so our results are related to the dry weight of the samples and/or wet weight.

One gram was taken from the dried grinded sample into a flask. 5 $\mathrm{ml}$ of nitric acid was added. The digestion flasks were kept overnight, and then putted on the hotplate at $80{ }^{\circ} \mathrm{C}$ until all the tissues were dissolved and the brown fumes of $\mathrm{NO}_{3}$ escaped, filtered and diluted till $25 \mathrm{ml}$ with distilled water. A blank was carried out in the same way.

\section{Preparation of the standard solutions:}

All metals were determined against aqueous standards. Standards prepared at dilutions $0,0.5$ and $1 \mathrm{ppm}$. The elements analyzed were $\mathrm{Mn}$, $\mathrm{Cd}, \mathrm{Pb}, \mathrm{Ni}$ and Fe. Stock standard solutions (Merck, Germany) of each element were used to prepare calibration solutions to obtain calibration curves. 
The metal analyses of samples were carried out in the Central laboratory of the Faculty of the Veterinary Medicine, Assiut University using a ZEEnit $700 \mathrm{P}$ atomic absorption spectrophotometer. The contents of heavy metals are expressed as $\mathrm{mg} / \mathrm{kg}$ of the sample based on dry weight. Statistical analysis carried out by using Paired-Sample T Test to compare and describe results.

\section{RESULTS}

Table 1: Concentration $(\mathrm{mg} / \mathrm{kg}$ dry weight $)$ of the tested heavy metals in the examined imported and local filleted fish samples:

\begin{tabular}{|l|c|c|c|c|c|c|c|}
\hline \multirow{2}{*}{$\begin{array}{c}\text { Heavy } \\
\text { metals }\end{array}$} & \multicolumn{3}{|c|}{ Imported filleted fish } & \multicolumn{3}{c|}{ Local filleted fish } & \multirow{2}{*}{ Significance } \\
\cline { 2 - 6 } & Min & Max & Mean \pm SD & Min & Max & Mean \pm SD & \\
\hline Lead & 0.28 & 15.29 & $6.90 \pm 4.035$ & 0 & 13.51 & $5.17 \pm 4.91$ & N.S. \\
\hline Cadmium & 0 & 6 & $2.44 \pm 1.52$ & 0 & 6.29 & $2.15 \pm 1.95$ & N.S. \\
\hline Manganese & 0.7 & 8.38 & $4.74 \pm 2.89$ & 0.12 & 15.11 & $3.61 \pm 4.35$ & N.S. \\
\hline Nickel & 0 & 6.70 & $1.88 \pm 2.57$ & 0 & 12.41 & $3.74 \pm 3.52$ & N.S. \\
\hline Iron & 0 & 38.95 & $24 \pm 14.15$ & 20.74 & 54.31 & $30 \pm 12.56$ & N.S. \\
\hline
\end{tabular}

N.S. not significant

Table 2: Concentration $(\mathrm{mg} / \mathrm{kg}$ dry weight) of the tested heavy metals in the examined flitted Tilapia nilotica and Nile perch fish samples:

\begin{tabular}{|l|c|c|c|c|c|c|c|}
\hline \multirow{2}{*}{$\begin{array}{c}\text { Heavy } \\
\text { metals }\end{array}$} & \multicolumn{3}{|c|}{ Flitted Tilapia nilotica } & \multicolumn{3}{c|}{ Flitted Nile perch } & \multirow{2}{*}{ Significance } \\
\cline { 2 - 7 } & Min & Max & Mean \pm SD & Min & Max & Mean \pm SD & \\
\hline Lead & 6.99 & 13.5 & $10.50 \pm 2.69$ & 0 & 6.995 & $3.34 \pm 3.49$ & $*$ \\
\hline Cadmium & 4.33 & 6.29 & $4.60 \pm 0.63$ & 0 & 3.375 & $1.64 \pm 1.10$ & $*$ \\
\hline Manganese & 7.56 & 15.11 & $11.79 \pm 3.13$ & 0.123 & 1.312 & $0.73 \pm 0.49$ & $*$ \\
\hline Nickel & 5.95 & 8.94 & $7.596 \pm 1.29$ & 0 & 12.41 & $4.22 \pm 4.86$ & \multirow{2}{*}{ N.S. } \\
\hline Iron & 21.79 & 54.31 & $31.164 \pm 9.36$ & 9.08 & 47.05 & $27.96 \pm 12.75$ & N.S. \\
\hline
\end{tabular}

* Significant at $p 0.001$ 
Table 3: Frequency distribution and comparing between concentration of heavy metals in imported and local fish according to permissible limit of EOSQC (1993).

\begin{tabular}{|c|c|c|c|c|c|c|c|c|c|}
\hline \multirow{3}{*}{$\begin{array}{l}\text { Heavy } \\
\text { metals }\end{array}$} & \multicolumn{4}{|c|}{ Imported fish } & \multicolumn{4}{|c|}{ Local fish } & \multirow{3}{*}{$\begin{array}{l}\text { *P.L. } \\
(\mathrm{ppm})\end{array}$} \\
\hline & \multicolumn{2}{|c|}{ **M. P. L. } & \multicolumn{2}{|c|}{$* * *$ L.P.L. } & \multicolumn{2}{|c|}{ M. P. L. } & \multicolumn{2}{|c|}{ L.P.L. } & \\
\hline & No. & $\%$ & No. & $\%$ & No. & $\%$ & No. & $\%$ & \\
\hline Lead & 4 & 16 & 21 & 84 & 6 & 24 & 19 & 76 & 0.1 \\
\hline Cadmium & 5 & 20 & 20 & 80 & 7 & 28 & 18 & 72 & 0.1 \\
\hline Manganese & 6 & 24 & 19 & 76 & 8 & 32 & 17 & 68 & 0.5 \\
\hline Nickel & 0 & 0 & 25 & $100 \%$ & 0 & 0 & 25 & $100 \%$ & 10 \\
\hline Iron & 0 & 0 & 25 & $100 \%$ & 0 & 0 & 25 & $100 \%$ & 30 \\
\hline
\end{tabular}

* P.L. = permissible limit according to EOSQC (1993)

**M. P. L. = More than the permissible limit

*** L.P.L. $=$ Lower than the permissible limit

\section{DISCUSSION}

In the literature, heavy metal concentrations in the tissue of fish vary considerably among different studies (Chattopadhyay et al., 2002; Papagiannis et al., 2004), possibly due to differences in metal concentrations and chemical characteristics of water from which fish were sampled, ecological needs, metabolism and feeding patterns of fish and also the season in which studies were carried out. In the river, fish are often at the top of the food chain and have the tendency to concentrate heavy metals from water (Mansour and Sidky, 2002).

Lead could contaminate water from industrial and agricultural discharges, high ways or motor traffic and from mine (Sorensen, 1991). Lead residues could result in haematological, gastrointestinal and neurological dysfunction. Severe or prolonged exposure to $\mathrm{Pb}$ may also cause chronic nephropathy, hypertension and reproductive impairment. $\mathrm{Pb}$ inhibits enzymes, alters cellular calcium metabolism and slows nerve conduction (Elinder, 1985a).

The mean values \pm S.D. of $\mathrm{Pb}$ were $5.17 \pm 4.91$ and $6.90 \pm 4.035$ $\mathrm{mg} / \mathrm{kg}$ dry weight in local and imported filleted fish, respectively (Table 1). The concentration of the analyzed elements in relation to wet weight can be obtained by dividing its concentration in dry bases by five by using moisture content of the analyzed samples. This formula agree with (Khaled, 2004b), who reported that the concentration of dry weight can be 
obtained by multiplying the concentration of wet weight by five. This result was nearly harmony to those reported by Saleh (2004) and Ahmed and Hussein (2004). The result was higher than that recorded by ElNabawi et al. (1987) who found that the mean level of Lead was $0.42 \mu \mathrm{g} / \mathrm{g}$ , Zauke et al. (1999) who found $\mathrm{Pb}$ concentrations below the limit of detection (<0.3 mg kg-1 dry wt), and Labib et al. (2008) who found that the $\mathrm{Pb}$ concentration ranged from 0.12 to $0.53 \mathrm{ppm}$ wet weight in Tilapia nilotica, and Claris Lazera collected from five districts of Qena governorate, Upper Egypt, Metwally and Fouad (2008) who found that the mean lead levels in Tilapia nilotica caught from Nag-Hamady, Qena, Kous, Luxor and Esna in Egypt were 0.530 \pm 0.085 , 0.690 \pm 0.170 , $1.124 \pm 0.209,0.598 \pm 0.087$ and $0.446 \pm 0.079 \mathrm{ppm}$ wet weight, respectively. The level of $\mathrm{Pb}$ was lower than that found by Mohamed and Gad (2008).

Hodson et al. (1984) indicated that the Canadian $\mathrm{Pb}$ limit of 10 ppm was discontinued, but that of the British limit remains at $2 \mathrm{ppm}$ for fish. Abou-Arab et al. (1996) indicated that the FAO limit (1983) is 2.0 ppm. WHO (1990) indicated that $\mathrm{Pb}$ permissible limit is $2.0 \mathrm{ppm}$ for seafoods. Obodo (2002) reported the case of polluted species of fish from the lower course of the River Niger at Onitsha. His work showed that tilapia was polluted with $\mathrm{Pb}$ having a bio-concentration of $68.36 \mathrm{mg} / \mathrm{kg}$. The mean residuals level of lead detected by Ahmed and Hussein (2004) was 1.51 and $1.74 \mathrm{ppm} /$ wet weight for $M$. cephalus and T. nilotica, respectively. Oze et al. (2006) detected lead in a level of $25.58 \pm 1.2 \mathrm{mg} / \mathrm{kg}$ against the WHO safety limit of $2.5 \mathrm{mg} / \mathrm{kg}$.

Maximum level for $\mathrm{Pb}$ must not exceed $0.1 \mathrm{ppm}$ wet weight, respectively (EOSQC, 1993). According to EOSQC (1993) $16 \%$ of imported filleted fish and $24 \%$ of local exceed the permissible limit (Table 3).

From this study it was found that no significant difference in $\mathrm{Pb}$ level between local and imported filleted fish as shown in Table (1) but slightly higher in $\mathrm{Pb}, \mathrm{Cd}$ and $\mathrm{Mn}$ in Tilapia nilotica than Nile perch as recorded in Table (2) and this may be attributed to sensitivity of Tilapia nilotica for toxicity.

Cadmium can be found in all foodstuffs, and particularly high amounts occur in organs of cattle, seafood, and some mushroom species. Although the absorption of cadmium is low in the GI tract, it has a long biological half-life because it accumulates in the body. The International Agency for Research on Cancer has determined that cadmium is probably carcinogenic to humans (Stanley 2004). The sources for cadmium pollution are mining company, many industrial companies as those of pigments and stabilizers for plastics, sewage sludge applied to land and fertilizers 
(Mason, 1991). Extremely wide ranges of Cd concentrations have been reported in foodstuffs from various countries.

As shown in Table (1) cadmium mean levels were $2.15 \pm 1.95$ and $2.44 \pm 1.52 \mathrm{mg} / \mathrm{kg}$ dry weight in local and imported filleted fish, respectively, while the levels in Tilapia nilotica and Nile perch were $4.601 \pm 0.63$ and $1.641 \pm 1.10 \mathrm{mg} / \mathrm{kg}$ dry weight, respectively (Table 2). Gutenmann et al. (1988) showed that a frequently used food safety limit for $\mathrm{Cd}$ in food is $2 \mathrm{ppm}$. In 1993, Food and Agriculture Organization (FAO) limit for Cd is $0.5 \mathrm{ppm}$. WHO, (1990) indicated that Cd permissible limit is $2.0 \mathrm{ppm}$ for seafood. Data from reliable analyses performed in several countries (Elinder, 1985b; WHO/FAO, 2003) indicate that most foodstuffs have $\mathrm{Cd}$ concentrations in the range $0.005-0.100 \mathrm{mg} / \mathrm{kg}$ (mean values, wet weight). Atta et al. (1997) detected $\mathrm{Pb}$ and $\mathrm{Cd}$ in a concentration of 12.1 and $1.92 \mathrm{mg} / \mathrm{kg}$ dry weight respectively in raw flesh Tilapia nilotica fish. Cadmium was detected in a mean residuals levels of 0.60 and $0.77 \mathrm{ppm}$ wet weight for $M$. cephalus and $T$. nilotica, respectively (Ahmed and Hussein, 2004). Al-Kahtani (2009) detected Cd in Oreochromis niloticus in a total average of $0.28 \mathrm{mg} / \mathrm{kg}$ dry weight. Maximum level for Cd must not exceed $0.1 \mathrm{ppm}$ wet weight, respectively (EOSQC, 1993). According to EOSQC (1993) $20 \%$ of imported and $28 \%$ of local filleted fish exceed the permissible limit (Table 3 ).

This result agreed with Labib et al. (2008) who found that the Cd concentration ranged from 0.32 to $0.42 \mathrm{ppm}$ wet weight, but higher than El-Nabawi et al. (1987) who reported that the Cd level in the examined muscle tissues of Tilapia nilotica caught from Abo-Qir Bay, Edku and Maruit lakes ranged from 0.018 to $0.023 \mu \mathrm{g} / \mathrm{gram}$. Also higher than Sorensen, (1991), Oehlenschlarger (1990) and Zauke et al. (1999) who found $\mathrm{Cd}$ concentrations was below $0.1 \mathrm{mg} \mathrm{kg}-1$ dry wt, while less than Tariq et al. (1994) and Saleh (2004).

Manganese is essential for formation of thyroxin, vit. K production and is effective in increasing copper excretion from the body (Committee on Dietry Allowance, Food and Nutrition Board, 1980).

Mean levels of $\mathrm{Mn}$ were $3.61 \pm 4.35$ and $4.74 \pm 2.89 \mathrm{mg} / \mathrm{kg}$ dry weight in local and imported filleted fish sample, respectively (Table1). The mean levels in filleted Tilapia nilotica and Nile perch were $11.793 \pm 3.13$ and $0.73 \pm 0.49 \mathrm{mg} / \mathrm{kg}$ dry weight, respectively (Table 2). $24 \%$ of imported filleted fish and $32 \%$ of local had Mn content exceeded the permissible limit proposed by EOSQC (1993) (Table 3).

Levels of Mn considered in harmony with Khaled (2004a, b). The result was lower than that found by Mohamed and Gad (2008), but higher than the result found by Rashed (2001). 
Concentrations of $\mathrm{Ni}$ in local and imported filleted fish were $3.74 \pm 3.52$ and $1.88 \pm 2.57 \mathrm{mg} / \mathrm{kg}$ dry weight, respectively (Table 1). Concentrations in filleted Tilapia nilotica and Nile perch were 7.596 \pm 1.29 and $4.217 \pm 4.86 \mathrm{mg} / \mathrm{kg}$ dry weight respectively (Table 2). According to EOSQC (1993) all samples were lower than the permissible limit (Table 3). The result was lower than the result recorded by Khaled (2004a), but higher than that recorded by Zauke et al. (1999) who found $\mathrm{Ni}$ concentration below $1 \mathrm{mg} \mathrm{kg}-1$ dry wt in muscle tissues of 15 marine fish species.

In local and imported filleted fish samples concentrations of iron were $30 \pm 12.56$ and $24 \pm 14.15 \mathrm{mg} / \mathrm{kg}$ dry weight, respectively (Table 1). Concentrations in Tilapia nilotica and Nile perch were $31.164 \pm 9.36$ and $27.96 \pm 12.75 \mathrm{mg} / \mathrm{kg}$ dry weight, respectively (Table 2). According to EOSQC (1993) the concentrations measured in all samples were lower than the permissible limit (Table 3). The result was lower than that reported by Mohamed and Gad (2008). These results agree with Abou- Arab et al. (1996) who found that $\mathrm{Mn}$ and Fe were lower than the permissible limits proposed by FAO.

Lead level in this study was lower than the permissible limit proposed by FAO (1983), while results of Mn and Fe were lower than that recorded by Mansour and Sidky (2002).

In Nasser Lake, Egypt two species (Tilapia nilotica, named Bolti, and Karmout) were used by Rashed (2001) as a biomarker for water pollution with metals. The result reveals that heavy metals in different water samples except $\mathrm{Cu}$ and $\mathrm{Zn}$ were more than the recommended permissible levels by EQSAC (1993). Iron level in Hawamdia and KaferEl-Zayat Tilapia nilotica samples (63.4 and $54.7 \mu \mathrm{g} / \mathrm{g}$ respectively) was more than its permissible levels; these may be due to the discharge of the adjacent chemical factories that used $\mathrm{Fe}$ in their processing. Karmout fish from the same locations (Kafer El-Zayat and Hawamdia) had lower concentration of $\mathrm{Cu}, \mathrm{Zn}, \mathrm{Ni}, \mathrm{Cd}$ and $\mathrm{Pb}$ than bolti, while $\mathrm{Fe}$ present in higher concentration in bolti than in Karmout Fish of farms exhibit lower concentrations of $\mathrm{Cu}, \mathrm{Ni}, \mathrm{Zn}, \mathrm{Fe}$ and $\mathrm{Co}$ than those from River Nile. This indicates that the fish especially Bolti was a good indicator for metal pollution.

From this study, it was concluded that there was no significant difference in analyzed heavy metal concentration between the examined local and imported fillet fish. The concentrations of $\mathrm{Pb}, \mathrm{Cd}$ and $\mathrm{Mn}$ were slightly higher in filleted Tilapia nilotica than Nile perch. 


\section{REFERENCES}

Abou-Arab, A.A.K.; Ayesh, A.M.; Amra, H.A. and Naguib, K. (1996): Characteristic levels of some pesticides and heavy metals in imported fish. Food Chemistry, 57(1): 1-6.

Ahmed, A.M. and Hussein, M.M. (2004): Residual Levels of Some Heavy Metals in Fish Flesh and Water from El-Manzala Lake, Egypt. J. King Saud Univ., Vol. 16, Agric. Sci. (2), pp. 187-196.

Al-Kahtani, M.A. (2009): Accumulation of Heavy Metals in Tilapia Fish (Oreochromis niloticus) from Al-Khadoud Spring, Al-Hassa, Saudi Arabia. American Journal of Applied Sciences 6 (12): 2024-2029.

AOAC (2006): Association of Official Agricultural Chemists Method 999.11. The method available at internet:

www.aoac.org/omarev1/999_11.pdf

Atta, M.B.L.A. El-Sebaie; Noaman, M.A. and Kassab, H.E. (1997): The effect of cooking on the content of heavy metals in fish (Tilapia nilotica). Food Chemistry 58: 1-4.

Censi, P.; Spoto, S.E.; Saiano, F.; Sprovieri, M.; Mazzola, S.; Nardone, G.; Di Geronimo, S.I.; Punturo, R. and Ottonello, D. (2006): Heavy metals in coastal water systems. A case study from the north western Gulf of Thailand. Chemosphere, 64: 1167-1176.

Chattopadhyay, B.; Chatterjee, A. and Mukhopadhyay, S.K. (2002): Bioaccumulation of metals in the East Calcutta wetland ecosystem. Aquat. Ecosys. Health Manag., 5(2): 191-203.

Committee on Dietry Allowance, Food and Nutrition Board, (1980): Recommended dietary allowance, $9^{\text {th }}$ revised edition, National Acadmey of Science: Washintogn DC.

Elinder, C.G. (1985a): "Cadmium: Uses, Occurrence and Intake in Cadmium and Health." A Toxicological and Epidemiological Appraisal, Volume 1, pp 23-63.

Elinder, C.G. (1985b): In "Cadmium and Health. A Toxicological and Epidemiological Appraisal." (L. Friberg, C.-G. Elinder, T. Kjellstrom, et al., Eds.), Ch. 3. CRC Press, Boca Raton, FL.

El-Nabawi, A.; Heinzow, B. and Kiruse, H. (1987): As, Cd, Cu, Pb, Hg and $\mathrm{Zn}$ in fish from Alexandria region, Egypt. Bull. Environ. Contam. Toxico., 39, 889-897.

EOSQC (1993): Egyptian Organization for Standarization and Quality Control. Maximum level for heavy metal concentrations in food. ES 2360-1993.UCD 546, 19: 815, Egypt. 
FAO (1983): Compilation of legal limits for hazardous substances in fish and fishery products. FAO Fishery Circular No. 464, pp. 5-100.

Fernandes, C.; Fontaínhas-Fernandes, A.; Cabral, D. and Salgado, M.A. (2008): Heavy metals in water, sediment and tissues of Liza saliens from Esmoriz-Paramos lagoon, Portugal. Environ. Monit. Assess. 136: 267-275.

Friberg, L. (1984): Cadmium and the kidney. Environ Health Perspect $54: 1-11$.

Gutenmann, W.H.; Bache, C.A.; McCahan, J.B. and Lisk, D.J. (1988): "Heavy Metals and Chlorinated Hydrocarbons in Marine Fish Products." Nutri. Reports Int., 38, 1157-1161.

Guven, K.; Ozbay, C.; Unlu, E. and Satar, A. (1999): Acute Lethal Toxicity and Accumulation of Copper in Gammarus pulex (L.) (Amphipoda). Turkish Journal of Biology, 23, 513-521.

Hodson, P.V.; Whittle, D.M.; Wong, P.T.; Borgmann, U.; Thomas, R.L.; Chau, Y.K.; Nriagu, J.O. and Hallett, D.J. (1984): "Lead Contamination of the Great Lakes and Its Potential Effects on Aquatic Biota." Advances.

Kalay, M.; Ay, O. and Canli, M. (1999): Heavy metal concentrations in fish tissues from the Northeast Mediterranean Sea. Bull. Environ. Contam. Toxicol. 63: 673-681.

Khaled Azza (2004a): "Heavy metals concentrations in certain tissues of five commercially important fishes from El-Mex Bay, Alexandria, Egypt" Egypt J. Aquat. Biol. and Fish. 8(1): 51-64.

Khaled Azza (2004b): "Seasonal concentrations of some heavy metals in muscle tissues of Siganus rivulatus and Sargus sargus from ElMex Bay and Eastern Harbour, Alexandria, Egypt" Egypt J. Aquat. Biol. and Fish. 8(1): 65-81.

Labib, H.Y.; Nassar, A.; Ahmed, A. and Shaker, A. (2008): Pollution of Nile fish by some heavy metals at Qena, Upper Egypt. Fourth International Conference for Development and the Enviroment, King Saud Univ.

MacFarlane, G.B. and Burchettt, M.D. (2000): Cellular distribution of Cu, $\mathrm{Pb}$, and $\mathrm{Zn}$ in the Grey Mangrove Avicemnia marina (Forsk.). Vierh Aquatic Botanic, 68: 45-59.

Mansour, S.A. and Sidky, M.M. (2002): Ecotoxicological Studies. 3. Heavy metals contaminating water and fish from Fayoum Governorate, Egypt. Food Chemistry 78: 15-22.

Mason, C.F. (1991): Biology of freshwater pollution. 2nd Edition; Longman New York. p. 351. 
Metwally, A.A. and Fouad, I.M. (2008): Biochemical Changes Induced by Heavy Metal Pollution in Marine Fishes at Khomse Coast, Libya. Global Veterinaria 2 (6): 308-311.

Mohamed, A.S.F. and Gad, S.N. (2008): Environmental pollution induced biochemical changes in tissues of Tilapia zilli, Solea vulgaris and Mugil capito from lake Qarun, Egypt. Global veterinaria 2 (6): 327- 336.

More, T.G.; Rajput, R.A. and Bandela, N.N. (2003): Impact of heavy metals on DNA content in the whole body of freshwater bivalve, Lamelleiden marginalis. Environ. Sci. Pollut. Res., 22: 605-616.

Obodo, G.A. (2002): The bioaccumulation of Heavy Metals in Fish From the Lower Reaches of River Niger J. Chem Soc. Nigeria 27(2): 173-76.

Oehlenschläger, J. (1990): Phosphorous content of muscle of white fish types from the North Atlantic. Informationen für die Fischwirstschaft, 37: 4, pp. 149-158.

Oze, G.; Oze, R.; Anunuso, C.; Ogukwe, C.; Nwanjo, H. and Okorie, K. (2006): Heavy Metal Pollution Of Fish Of Qua-Iboe River Estuary: Possible Implications For Neurotoxicity. The Internet Journal of Toxicology. 3, 1 .

http://www.ispub.com/ostia/index.php?xmlFilePath=journals/ijto/ vol3n1/metal.xml

Papagiannis, I.; Kagalou, I.; Leonardos, J.; Petridis, D. and Kalfakaou, V. (2004): Copper and zinc in four freshwater fish species from Lake Pamvotis (Greece). Environ. Int., 30: 357-362.

Rashed, M.N. (2001): Monitoring of environmental heavy metals in fish from Nasser Lake Environ. Intern. P. 27-33.

Saleh, E.A. (2004): Monitoring of some heavy metals residues in some fish. Alex.J.VET.. 21, 1: $324-331$.

Shibamoto, Y. and Bjeldanes, L.F. (1993): Introduction to food toxicology. Academic Press, Inc. Harcourt Brace and company. New York. Food Science and Technology, International Series.

Sorensen, E.M. (1991): Cadmium. Metal poisoning in fish. CRC Press, Boca Raton, Florida.

Stanley, T.O. (2004): Food and Nutritional Toxicology. By CRC Press LLC, Boca Raton London New York Washington, D.C.

Storelli, M.M.; Giacominelli-Stuffler, R.; Storelli, A. and Marcotrigiano, G.O. (2005): Accumulation of mercury, cadmium, lead and arsenic in swordfish and blue fin tuna from the Mediterranean Sea: A comparative study. Marine Pollution Bulletin, 50: 1004-1007. 
Tariq, J.; Japffar, M.; Ashraf, M. and Moazzam, M. (1994): Heavy metal concentrations in fish, shrimp, seaweed, sediment and water from the Arabian Sea, Pakistan. Marine Pollution Bulletin, 26: 644-647.

Tüzen, M. (2003): Determination of heavy metals in fish samples of the Mid Dam Lake Black Sea (Turkey) by graphite furnace atomic absorption spectrometry. Food Chemistry, 80: 119-123.

WHO. (1990): "Guidelines for Seafood Quality." 2nd. ed., V(1), Recommendation, WHO Geneva.

WHO/FAO. (2003): Joint Expert Committee on Food Additives and Contaminants.

Zauke, GP.; Savinov, VM.; Ritterhoff, J. and Savinova, T. (1999): Heavy metals in fish from the Barents Sea (summer 1994). Sci Total Environ. 9; 227(2-3): 161-73. 